\title{
Wireless Library Management System Using Smartphone
}

\author{
Mr. Shubham Garate ${ }^{1}$, Miss. Manisha Kadam ${ }^{2}$ \\ Student, Bachelor of Engineering, Electronics \& Telecommunication Engineering Department, Dr. Daulatrao Aher \\ College of Engineering, Karad, Maharashtra, India ${ }^{1}$ \\ Assistant Professor, Electronics \& Telecommunication Engineering Department, Dr. Daulatrao Aher College of \\ Engineering, Karad, Maharashtra, India ${ }^{2}$
}

\begin{abstract}
Library is a fast growing sector. A properly updated library will provide most of services to its user. Library management system which is helps for maintaining a database of number of various books to be borrow, return and recording the information of the registered students and librarian also to identify the student identification by using RFID card. With the help of RFID card and tags of the student's database and books will be loaded on it and paperless work will be done within limited or in very few seconds. This will help in less time consumption. The books which are limited it should be properly circulated amongst all members. So we will be introducing a reservation system for members in which the users can reserve his/her books through GPRS. The number of members can be reserved but first preference will be given to reserved member. Along with this process GPRS technology is also used in order to send message to respective student regarding the due date of the book issued by the student and the fine applicable if the book is not returned on time. The proposed system gives information to the student whether the book to be issued is available or not available. It will be helpful to all library members, so they consume their time and chaos condition in library.
\end{abstract}

Keywords: GPRS, GSM MODULE, radio frequency identification (RFID), EMBEDDED SYSTEM, ANDROID.

\section{INTRODUCTION}

\section{Pre-computerization:}

Before computerization, library tasks were performed independently from each other. They ordered materials with ordering slips and indexed them by using card system. The fines were collected by librarian. The students signed books out manually by indicating their name on cards which were collected at the library circulation desk.

1960s: the influence of computer technologies:

In era 1960s, the next biggest innovation came with computer technologies.

The library automation were innovates; they began experiment in the mid 1960s onward.

\section{0s-1980s: the early integrated library system:}

The improvements were established in computer storage as well as in telecommunication. Due to this improvement ILS were established.

The ILS were includes hardware and software which allowed control over the library tasks.

All the remaining library task were accomplished through ILS as well as cataloguing.
All remaining library task were accomplished through ILS as well as cataloguing.

1990s-2000s: the growth of the Internet:

In era 1990s to 2000s, Library users were engaged with their library through online web based portals.

Library users log into their library accounts for reservation as well as renew books.

The ILS were grew exponentially in this era's than in 1982.

Mid 2000s-Present: increasing costs and customer dissatisfaction:

Most of the services were provide by ILS vendors with increasing cost. At the same moment, ILS was in its fast testing.

Today most of the libraries began to use the open source ILS as Koha and Evergreen.

Most of the common problems were noted to avoid vendor lock in and license fees. Library were accepted all kind of freedom, according to their request. 


\section{PROPOSED SYSTEM}

Block Diagram:

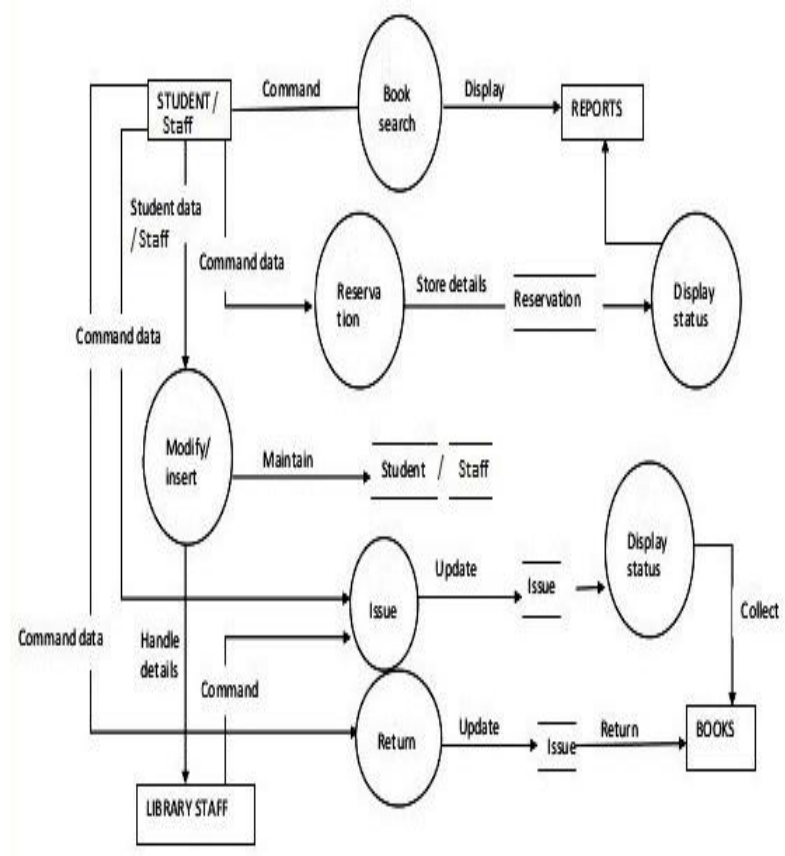

Fig.2.1.Proposed system

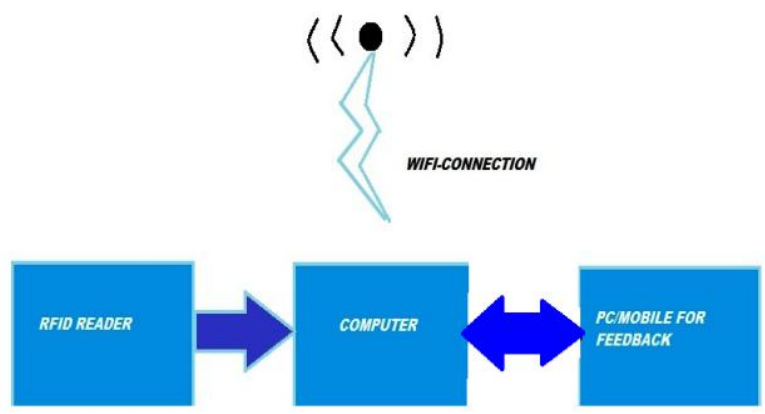

Fig.2.2. Block Diagram

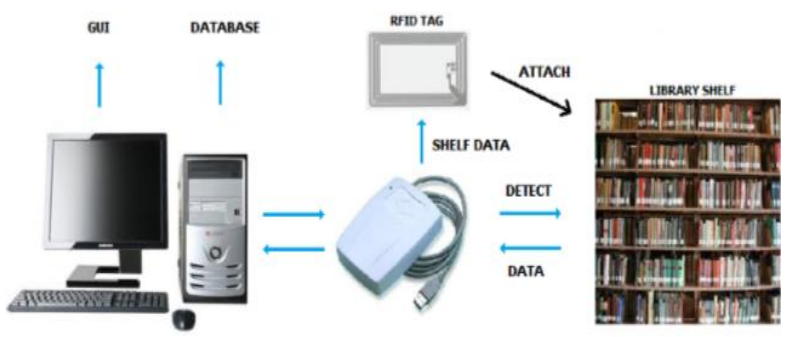

HOST COMPUITR

Fig. 2.3.Conceptual Design

\section{WORKING}

As per proposed block diagram the working of proposed block diagram is as follows first the students/staff registration will take place in a manner such that the user will register himself /herself with the help of android application/manually. After registration the user can access the library data-base of book and can carry out the issue/return operation frequently. This all register data is store to librarian main severe. Now the user is able to use the facilities of library in such a way that he/she can access the library number books data-base of every year, (i.e. FE to $\mathrm{BE}$ ) every trade. The user can search required books on the android application in this the user will be able to trace the location of the book required.Once the book is located the user has to just take the book and go at the librarian counter were he/she only has to swipe the RFID card given to him as ID card. The librarian only has swipe. The books over RFID reader, so that information of book store on tag stick will be displayed on the librarian display. After that the information of user will taken through his/her ID card. Then librarian will match information and issue/return the books to the user. Now, what happen if there is limited stock of book then very less students/ staff can use it for a long period. So, here we introduce one of the feature of our project is reservation of book were the user can reserve books such that if the first user has issued the book for 15 days then next user can reserve the book and he will get the message one day early that the xyz user has to returned it on $15^{\text {th }}$ day. Reservation preference will be given to first member who will reserve book first. If someone has not returned the book after given date then the xyz user will be informed through the GSM system via text message so that the user should be alert about the book returning on time. GSM system is only used for alerting user to return their book on time so that everyone will get benefits of it. His all record of books issued/returned, reservation will be recorded on librarian $\mathrm{PC}$ so as to maintain the catalogue. This project also gives facility to the students/staff to request books all particular subjects which are required or available in limited stock at library. Daily record will be maintained of books issued/returned to the user. The all work is paperless work and less time consuming such that in chaos condition also the librarian will able to carry out the operation frequently.

\section{HARDWARE REQUIREMENTS}
1. Computer.
2. RFID Reader.
3. RFID Tags.
4. RS232 female connectors.
5. USB cable with RS232 male connector.
6. GSM Module.
7. Connecting wires.

\section{A. RFID Reader Module:}

The RFID Reader module is having low frequency about $125 \mathrm{KHz}$. It has serial output with at the range of 8-12 Cm. It was found in some antennas with the compact units. By using RS232 protocol it is directly to computer.

\section{Features}

1. Serial and TTL output 
2. Along with two RFID cards

3. Excellent read performance

4. Compact size and cost effective

\section{Applications}

1. Access control

2. Handheld readers

3. Asset management

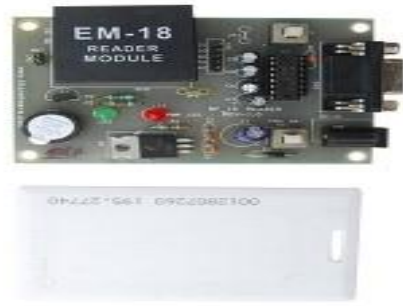

Fig.4.1. RFID Reader Module
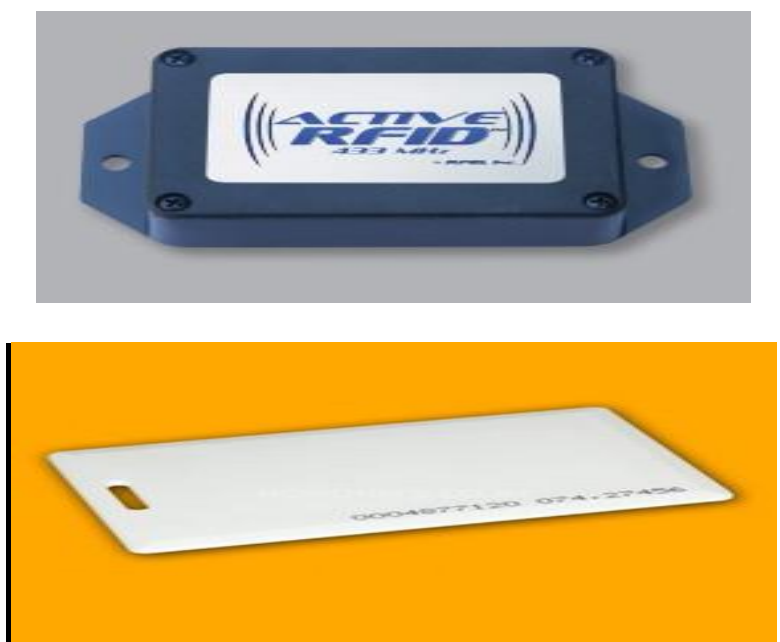

Fig..4.2: Active Tag and Passive Tag

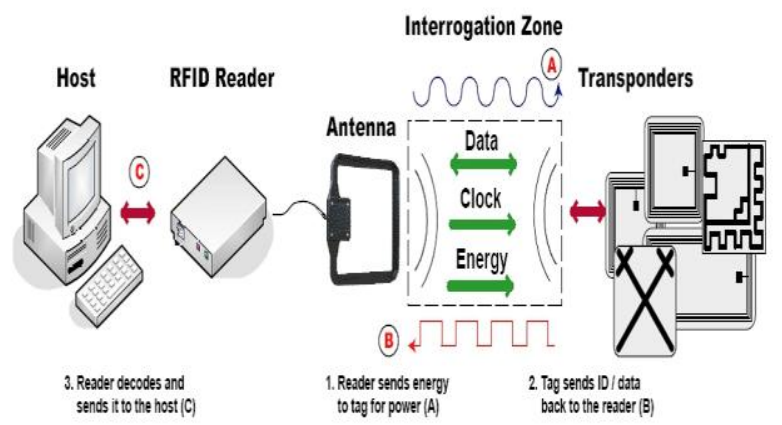

Fig.4.3. RFID Module Working

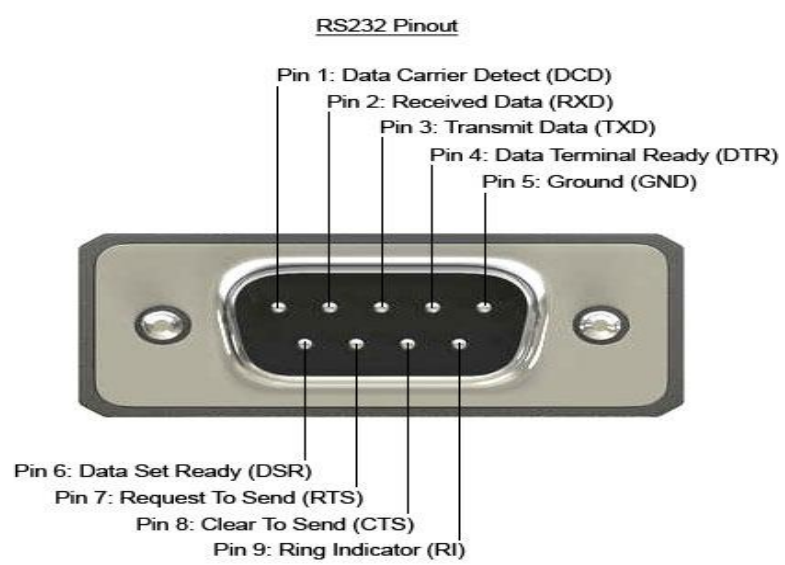

Fig.4.4. RS232 Pin out

Serial transmission involves the sending of data one bit at a time, over a single communications line. In contrast, parallel communications require at least as many lines as there are bits in a word being transmitted (for an 8-bit word, a minimum of 8 lines are needed). Serial transmission is beneficial for long distance communications, whereas parallel is designed for short distances or when very high transmission rates are required.

\section{GSM Module :}

GSM (Global System for Mobile) / GPRS (General Packet Radio Service) TTL -Modem is SIM900 Quad-band GSM / GPRS device, works on frequencies $850 \mathrm{MHZ}, 900$ MHZ, 1800 MHZ and 1900 MHZ. It is small in size and easy to operate. The modem is operated over $5 \mathrm{~V}$ DC and user can be directly interface with microcontroller. The baud rate can be variable from 9600 115200 bps through AT. The GSM model inbuilt available TCP/IP stack to enable user through GPRS features. It is suitable for SMS as well as DATA transfer application in mobile phone to mobile phone interface.

\section{Features:}

- Works on frequencies in GSM: 850 / 900 / 1800 / 1900 $\mathrm{MHz}$

- Connecting through RS232 or Max 232

- Proportional baud rate

- SIM (Subscriber Identity Module) slot available here

- LED shows current network status

- Packets transfer through GPRS (General Packet Radio Service)

- Operating Temperature: $-20{ }^{\circ} \mathrm{C}$ to $+55^{\circ} \mathrm{C}$

- Operating Voltage: $5 \mathrm{~V}$ to $12 \mathrm{~V}$ DC

\section{SOFTWARE REQUIREMENTS}

\section{B. RS232:}

Information is in the form of digital data is transferred between data processing unit and peripherals through either serially or parallel. Parallel communications are used mainly for connections between test instruments or computers and printers, while serial is often used between computers and other peripherals.
For this particular project the software required are as follows:

1. C\#.NET

2. Visual Studio 2015 
3. .NET Framework 5.4
4. Eclipse
5. Visual Basic
6. GUI

\section{CONCLUSION}

The issues \& problems faced in the library were identified and the system is designed to promote an easy access for a Librarian to maintain the library and also for the user to ease access of the books, articles, CD's, Journals, etc., The design of the system is carried out based on the ideas to rectify the system with the identified errors as a token of enhancement work. The requirements were pointed out and the study of the requirements was done. RFID in the library help for book issuing and returning with speedily. RFID technology play vital role in library management it has fast growing, high Recurrence capability with wide range.

\section{FUTURE APPLICATION}

In future the tag system can be implemented in any type of asset tracking, especially in multi-national offices to keep track in their office files, often DVDs. It can also be used in laboratories for tracking of equipments. RFID can be implemented in public transits for avoidance of unauthorized travel.

\section{REFERENCES}

1. A Pravi Renold, Joshi Rani R"INTERNET BASED RFID LIBRARY MANAGEMENT SYSTEM" IEEE CONFERENCE PAPER ON INFORMATION AND COMMUNICATION TECHNOLOGY (ICT2013)

2. R. Dinesh, S. Arun,Pravin, M. Aravindhan "LIBRARY ACCESS SYSTEM APPLICATION USING ANDROID " IJCSMC Vol.4, Issue. 3,March 2015

3. Dhanalakshmi M, Uppala Mamatha "RFID BASED LIBRARY MANAGEMENT SYSTEM” IJACSA, Vol.2,No.1,July 2013

4. Ahmad Tarmizi Bin Abdullah, Ismarani Binti Ismai, Azlina Binti Ibrahim Mohd, Zikrul HakimBin Noor "LIBRARY SELF MANAGEMENT SYSTEM USING RFID TECHNOLOGY" ICSET, Vol.5, June 2011

5. Sree Lakshmi Addepalli, Sree Gowri Addepalli "LIBRARY MANAGEMENT SYSTEM USING RFID TECHNOLOGY" IJCSIT, Vol.5(6), 2014

6. Moiz S. Ansari, Naveed Ghani Khatri "AUTOMATED RFID BASED LIBRARY MANAGEMENT SYSTEMS” ICS, Vol.4,2011

7. Priyanka Grover and Anshul Ahuja "RADIO FREQUENCY IDENTIFICATION BASED LIBRARY MANAGEMENT SYSTEM” IJACSA, Vol.1 ,No.1,July 2010

8. www.wikipedia.org- Library 